\title{
PENGARUH HARGA DAN FAKTOR EKSTERNAL TERHADAP PERMINTAAN EKSPOR KOPI DI INDONESIA
}

\author{
Lukman \\ UIN Syarif Hidayatullah Jakarta \\ lukmanroka@yahoo.co.id
}

\begin{abstract}
The objectives of the research are to know the influence relative price and external factor i.e. exchange rate, and real GDP exporting country of volume Indonesia export coffee. The data used in this research is secondary data in forms of time series. Analytical method used in the study is Ordinary Least Square method. The result of this research indicated that relative price, Real GDP, and lag export volume are affected significantly and positively upon of volume export. Exchange rate affected non-significantly upon of Indonesia export coffee to United States. While for England: Exchange rate and lag export volume affected significantly and positively upon of volume export. Relative price and Real GDP do not affected significantly upon of volume Indonesia export coffee. If the relative price changed and external factors (i.e. foreign price, exchange rate, real GDP exporting country) will influenced to Indonesian total export coffee.
\end{abstract}

Keywords: Relative Price; Real GDP; Exchange Rate; Export Volume

\begin{abstract}
Abstrak
Tujuan dari penelitian ini adalah untuk mengetahui pengaruh harga relatif dan faktor nilai tukar yaitu eksternal, dan PDB riil negara pengekspor volume ekspor kopi Indonesia. Data yang digunakan dalam penelitian ini adalah data sekunder dalam bentuk time series. Metode analisis yang digunakan dalam penelitian ini adalah metode Ordinary Least Square. Hasil penelitian ini menunjukkan bahwa harga relatif, GDP riil, dan lag volume ekspor dipengaruhi secara signifikan dan positif pada ekspor volume. Nilai tukar dipengaruhi non-signifikan pada kopi ekspor Indonesia ke Amerika Serikat. Sedangkan untuk Inggris: Kurs dan lag volume ekspor terpengaruh secara signifikan dan positif pada ekspor volume. harga relatif dan PDB riil tidak terpengaruh secara signifikan pada volume ekspor kopi Indonesia. Jika harga relatif berubah dan faktor eksternal (yaitu harga luar negeri, nilai tukar, PDB riil negara pengekspor) akan dipengaruhi total ekspor kopi Indonesia.
\end{abstract}

Kata Kunci: Harga Relatif; PDB Riil; Nilai Tukar; Volume Ekspor 


\section{PENDAHULUAN}

Komoditas perkebunan rakyat sampai saat ini masih berperan sebagai andalan penghasil devisa non-migas dari sektor pertanian. Produk yang diekspor sudah sangat bervariasi, mulai dari jenis biji sampai kepada komoditas yang telah mengalami berbagai tingkat pengolahan. Jangkauan pasarnya juga sangat luas, baik di negara-negara maju seperti Amerika Serikat, negara-negara di kawasan Eropa, Jepang dan Singapura, maupun negara- negara sedang berkembang di Asia dan Amerika Latin. Ekspor komoditas perkebunan Indonesia sebagian besar masih dalam bentuk komoditas primer. Sebagai contoh volume ekspor kopi Indonesia 97.7 persen masih dalam bentuk biji kopi. Demikan pula volume ekspor kakao 80.4 persen masih dalam bentuk biji kakao dan untuk ekspor teh 95.6 persen masih dalam bentuk teh curah (Ibnusantosa, 2000 dalam Lembaga Riset Perkebunan Indonesia, 2006).

Selama periode 1999-2009 luas perkebunan tanaman kopi mengalami peningkatan sebesar $0.81 \%$, dengan luas tertinggi pada tahun 2005 sebesar $1.381 .730 \mathrm{Ha}$, Meskipun terjadi adanya peningkatan luas areal tanaman perkebunan kopi selama periode 1995-2005 namun peningkatan ini tidak diikuti dengan peningkatan produksi tanaman kopi, Pada periode tahun 2008-2009 produksi tanaman kopi mengalami penurunan rata-rata sebesar $-12.99 \%$. Realisasi ekspor kopi Indonesia dalam perkembangan akhir-akhir ini mengalami penurunan volume ekpor. Pada tahun 1999 volume ekspor kopi Indoensia mencapai 230.201 ton dengan nilai ekspor US\$ 606.369 sedangkan pada tahun 2009 volume ekspor kopi hanya mencapai 445.829 ton dengan nilai US\$503.836. Volume ekspor mengalami fluktuasi sejak tahun 1999 sampai dengan tahun 2001. Namun selama 3 tahun berturut-turut sejak tahun 2003 sampai dengan 2005 persentase peningkatan volume ekspor cenderung menunjukan penurunan. Sejalan dengan penurunan persentase volume ekspor juga diikuti dengan penurunan nilai ekspor. Namun, ekspor kopi mulai menunjukkan peningkatan kembali pada tahun 2009 . 
Secara umum kendala pokok dalam peningkatan ekspor pertanian adalah pertama kendala dari sisi permintaan/ekspor (eksternal) paling tidak ada lima faktor yang menghambat ekspor yaitu (1) permintaan hasil-hasil pertanian yang bersfiat in-elastis, (2) tingkat pertumbuhan penduduk negara maju hampir mendekati nol persen, (3) elastisitas pendapatan atas permintaan yang relatif rendah, (4) berkembannya produk-proudk subtitusi (sintetis), dan (5) adanya proteksi dari negara-negara maju. Kedua, kendala dari sisi penawaran (internal) yang paling penting adalah kekakuan struktur sistem produksi di negara produsen hasil pertanian, seperti terbatasnya sumberdaya modal, iklim yang tidak menguntungkan, sistem kelembagaan yang relatif terbelakang dan adanya struktur sosial ekonomi yang tidak produktif (Todaro, 1993).

Menurut Pangestu, secara umum beberapa faktor yang menyebabkan menurunnya ekspor Indensia antara lain : (1) kenaikan biaya tenaga kerja, disebabkan kenaikan upah (UMR) yang lebih tinggi dari pada produktivitas. Biaya tenaga kerja (dalam USD) setelah krisis 35\% lebih tinggi dibandingkan sebelum krisis; (2) peningkatan biaya ekonomi tinggi yang disebabkan adanya pungutan-pungutan resmi (pajak, bea cukai) maupun tidak resmi (pungutan tambahan yang berkaitan dengan birokrasi), masalah ekonomi tinggi ini mempunyai dampak langsung terhadap biaya produksi; (3) Prasarana yang tidak mendukung, mengakibatkan rendahnya kinerja ekspor. Prasarana transportasi dan pelabuhan yang tidak mendukung telah menyebabkan meningkatnya biaya ekspor Indonesia, sebagian besar ekspor Indonesia menggunakan kontainer dikapalkan melalui Singapura dan Malaysia serta tidak efisiennya pelabuhan Indonesia (Pangestu, 2004).

Permintaan ekspor kopi Indonesia (volume ekspor) selain dipengaruhi oleh harga komoditas di dalam negeri, juga dipengaruhi oleh faktor luar negeri (eksternal) yaitu harga komoditas tersebut di luar negeri, nilai tukar, dan GDP riil negara tujuan ekspor. Disamping harga, besarnya nilai tukar mata uang diantara kedua Negara juga dapat mempengaruhi permintaan negara Amerika dan Inggris terhadap komoditas kopi dari Indonesia. Suatu depresiasi nilai kurs rupiah terhadap mata uang US Dollar dan Poundsterling, diduga dapat mendorong permintaan negara Amerika dan 
Inggris terhadap produk kopi dari Indonesia. Sedangkan suatu apresiasi nilai kurs rupiah terhadap mata uang US Dollar dan Poundsterling, diduga dapat menurunkan permintaan negara Amerika dan Inggris terhadap produk kopi dari Indonesia. Kemudian, permintaan terhadap komoditas ekspor kopi juga dipengaruhi oleh tingkat pendapatan nasional negara pengimpor. Pendapatan nasional suatu negara, menunjukkan kemampuan daya beli negara tersebut. Semakin besar pendapatan nasional suatu negara, semakin besar pula jumlah komoditas ekspor kopi yang diminta dari negara Indonesia. Sebaliknya, semakin kecil pendapatan nasional suatu negara, semakin kecil pula jumlah komoditas ekspor kopi yang diminta dari negara Indonesia.

Variabel lain yang diduga mempengaruhi permintaan terhadap komoditas ekspor kopi adalah nilai ekspor komoditas kopi tahun sebelumnya. Estimasi permintaan ekspor suatu negara terhadap terhadap suatu produk tertentu, kadangkala dipengaruhi secara psikologis oleh permintaan ekspor tahun sebelumnya. Pada setiap negara, rencana pembelian (permintaan) terhadap suatu produk impor dari Negara lain, secara psikologis dipengaruhi oleh data-data pembelian produk pada tahun sebelumnya. Hal yang sama terjadi pula pada permintaan komoditas kopi luar negeri terhadap komoditas kopi dari Indonesia, yang dipengaruhi oleh data komoditas kopi yang mereka beli dari Indonesia pada tahun sebelumnya.

Adapun negara tujuan ekspor yang akan dijadikan objek dalam penelitian ini adalah Amerika Serikat dan Inggris, karena kedua negara tersebut termasuk negara terbesar dalam menerima ekspor kopi dari Indonesia, serta kedua negara tersebut memiliki nilai kurs terbesar terhadap mata uang rupiah. Nilai kurs yang besar memiliki arti bahwa jika terjadi perubahan sedikit saja pada nilai mata uang tersebut (dolar atau poudsterling) maka akan berdampak besar pada permintaan produk yang diteliti (kopi).

Dalam penelitian ini penulis mencoba membuat spesifikasi model untuk mengkaji faktor-faktor yang mempengaruhi permintaan komoditas kopi ke Amerika dan Inggris, dari sisi harga komoditas tersebut di dalam negeri 
(domestik), dan faktor-faktor eksternal yang mempengaruhi ekspor yaitu harga komoditas tersebut di luar negeri, nilai tukar, serta GDP riil negara pengimpor. Rumusan identifikasi masalah yaitu bagaimana pengaruh harga relatif ekspor (rasio harga kopi di luar negeri terhadap harga kopi di dalam negeri), nilai tukar, GDP riil negara tujuan, dan ekspor kopi pada tahun sebelumnya baik secara bersama-sama maupun individu terhadap permintaan ekspor kopi Indonesia ke Amerika Serikat dan Inggris? Penelitian ini bermaksud untuk analisis Harga domestik dan Faktor eksternal yang berpengaruh terhadap ekspor kopi Indonesia ke Amerika Serikat dan Inggris selama periode 1985 - 2009. Untuk mencapai maksud tersebut, penelitian ini memiliki tujuan yaitu untuk mengetahui pengaruh harga relatif (rasio harga kopi di luar negeri terhadap harga kopi di dalam negeri), nilai tukar, GDP riil negara tujuan, dan ekspor kopi pada tahun sebelumnya, baik secara bersama-sama maupun individu terhadap permintaan ekspor kopi Indonesia.

Ekspor dipengaruhi oleh harga relatif dan pendapatan riil negara tujuan ekspor atau negara mitra dagang atau negara pengimpor, dan dapat dirumuskan sebagai berikut : (Batiz Fransisco L R dan Luis A. Reivera Batiz, 1994)

$$
\begin{aligned}
& X_{a}=f\left(P, Y_{b}\right) \text {; dengan } P=\frac{P_{B}}{P_{A}} \\
& \text { maka } X_{a}=f\left(P_{B} / P_{A}, Y_{b}\right)
\end{aligned}
$$

di mana :

$\mathrm{Xa}=$ volume atau kuantitas ekspor;

$\mathrm{P}=$ harga relatif (ratio antara harga barang dalam luar negeri dinegara $B$ terhadap harga barang di negara $A$,

$\mathrm{Y}_{\mathrm{b}}=\mathrm{Y}_{\mathrm{b}}$ pendapatan (GDP) negara $\mathrm{B}$.

$$
M=f(G D P) ; \frac{\partial M}{\partial G D P}>0
$$

Terdapat korelasi positif antara GDP dengan permintaan produk impor. Peningkatan GDP akan meningkatkan permintaan terhadap produk impor, demikian sebaliknya. Peningkatan impor sebagai akibat meningkatnya GDP 
negara importir. Formula yang digunakan untuk menentukan tingkat pertumbuhan ekonomi adalah

$$
g=\frac{\text { PNriil }_{1}-\text { PNriil }_{0}}{\text { PNriil }_{0}} \times 100
$$

di mana $\mathrm{g}$ adalah tingkat pertumbuhan ekonomi dan dinyatakan dalam persen. PNriil ${ }_{1}$ adalah pendapatan nasional untuk tahun di mana kadar pertumbuhan ekonominya dihitung dan PNriilo adalah pendapatan nasional pada tahun sebelumnya. Menghitung pendapatan nasional riil dengan mendefinikan pendapatan nasional pada harga masa kini dilakukan dengan menggunakan formula :

$$
\text { PNriil }_{i}=\frac{100}{H_{i}} x \text { PNmasakini } i_{i}
$$

dimana PNriil $_{i}$ adalah pendapatan nasional riil tahun $\mathrm{i}, \mathrm{HI}$ adalah indeks harga atau pen-deflasi pendapatan nasional (GNP deflator) dan PN masa kini adalah pendapatan nasional pada masa kini tahun i.

Kurs nominal dan kurs riil. Kurs nominal (nominal exchange rate) adalah harga relatif dari mata uang dua negara. Sebagai contoh, jika antara dolar Amerika Serikat dan yen Jepang adalah 120 yen per dolar, maka orang Amerika Serikat bisa menukar 1 dolar untuk 120 yen di pasar uang. Sebaliknya orang Jepang yang ingin memiliki dolar akan membayar 120 yen untuk setiap dolar yang dibeli. Ketika orang-orang mengacu pada "kurs" diantara kedua negara, mereka biasanya mengartikan kurs nominal (Mankiw, 2003). Kurs riil (real exchange rate) adalah harga relatif dari barang - barang diantara dua negara. Kurs riil menyatakan tingkat dimana kita bisa memperdagangkan barang-barang dari suatu negara untuk barang-barang dari negara lain. Nilai Tukar (exchange rate) atau kurs adalah harga satu mata uang suatu negara terhdap mata uang negara lain (Krugman dan Obsfelt, 2000). Nilai tukar nominal (nominal exchange rate) adalah harga relatif dari mata uang dua negara (Mankiw, 2003).

Anggaplah perekonomian dunia terdiri dari dua negara, kita namakan Domestik (yang mengekspor kain) dan Asing (yang mengekspor makanan). Nilai tukar perdagangan Domestik diukur dengan $P_{C} / P_{F}$, sementara Asing diukur dengan $P_{F} / P_{C}$. Untuk menentukan $P_{C} / P_{F}$ kita melihat pada 
perpotongan penawaran relatif dunia dan permintaan relatif dunia. Kurva penawaran relatif dunia ( $R S$ dalam Gambar 2.6) berbentuk (upward-sloping) menaik karena peningkatan $P_{C} / P_{F}$ membuat kedua negara memproduksi lebih banyak kain dan lebih sedikit makanan. Kurva permintaan relatif dunia $(R D)$ berbentuk menurun karena peningkatan $P_{C} / P_{F}$ menyebabkan kedua negara mengalihkan konsumsinya dari kain ke makanan. Perpotongan kedua kurva ini (titik 1) menentukan keseimbangan harga relatif $\left(P_{C} / P_{F}\right)$. Dengan demikian dapat diketahui bagaimana penawaran relatif, permintaan relatif, nilai tukar perdagangan dan kesejahteraan ditentukan dalam model standar.

Sesuai dengan model ekonometri yang digunakan Teori Batiz Fransisco L R dan Luis A. Reivera Batiz (1994), Penelitan Kishor Sharma (2000), Penelitan Khumar dan Dhawan (1991) serta Penelitan Kusumadewi (2005) yang mengacu Teori Batiz and Batiz (1994), maka model yang digunakan dalam meneliti faktor - faktor yang mempengaruhi permintaan ekspor kopi Indonesia adalah sebagai berikut :

$$
\begin{gathered}
Q_{t}=f\left(P_{t}, I_{t}, E r_{t}, Q_{t-1}\right) ; \ldots \\
\text { dengan } P_{t}=P_{L N_{t}} / \boldsymbol{P}_{D N_{t}}
\end{gathered}
$$

Maka

$$
Q_{l}=f\left(P_{L N_{i}} / P_{D N_{t}}, I_{t}, E r_{r}, Q_{t-1}\right)
$$

atau dalam bentuk persamaan menjadi :

$$
Q_{t}=\beta_{0}+\beta_{1}\left[P_{L N_{t}} / P_{D N_{t}}\right]+\beta_{2} I_{t}+\beta_{3} E R_{t}+\beta_{4} Q_{t-1}
$$

\section{METODE}

Objek yang akan diteliti adalah variabel volume ekspor, variabel harga komoditas dalam negeri, variabel harga komoditas di luar negeri, variabel nilai tukar, Pendapatan riil negara tujuan ekspor, dan variabel ekspor komoditas tersebut pada periode tahun 1985 - 2009. 
Penelitian ini untuk mengetahui pengaruh harga relatif ekspor (harga luar negeri terhadap dalam negeri), pendapatan riil, nilai tukar (kurs), dan ekpor periode sebelumnya terhadap ekpor kopi Indonesia ke negara Amerika Serikat, dan Inggris. Untuk mengetahui pengaruh masing-masing variabel tersebut digunakan analisis regresi linier berganda dengan metode Ordinary Least Square (OLS). Adapun spesifikasi model penelitian yang akan diujinya adalah sebagaimana berikut ini :

$$
\begin{aligned}
& Q_{t}=f\left(P_{t}, I_{t}, E r_{t}, Q_{t-1}\right) ; \\
& \text { dengan } P_{t}=P_{L N_{t}} / P_{D N_{t}} \\
& \text { Maka } \\
& Q_{t}=f\left(P_{L N_{t}} / P_{D N_{t}}, I_{t}, E r_{t}, Q_{t-1}\right)
\end{aligned}
$$

di mana :

Q = volume ekspor komoditas kopi, satuan dalam ribu ton

$\mathrm{P}_{\mathrm{LN}} \quad=$ harga komoditas kopi di luar negeri, satuan dalam dollar $/ 100 \mathrm{~kg}$

$P D N=$ harga komoditas kopi dalam negeri (domestic), satuan dalam rupiah $/ 100 \mathrm{~kg}$

I = Pendapatan riil negara tujuan ekspor, satuan dalam milliar dollar

$\mathrm{ER}=$ nilai tukar mata uang (exchange rate)

$\mathrm{Q}_{\mathrm{t}-1}=$ kspor komoditas kopi tersebut pada tahun sebelumnya, satuan dalam ribu ton

Kemudian di ubah kedalam bentuk persamaan linier :

$$
Q_{i}=\beta_{0}+\beta_{1}\left[P_{L N_{i}} / P_{D N_{i}}\right]+\beta_{2} I_{i}+\beta_{3} E R_{i}+\beta_{4} Q_{t-1 i_{i}}
$$

Persamaan 13 ini digunakan dua kali, pertama untuk $i=1$ (Amerika Serikat) dan kedua untuk i=2 (Inggris), data yang dikumpulkan benar-benar valid dan andal maka dibutuhkan suatu alat ukur yang apabila digunakan akan menggambarkan keadaan sesungguhnya. Untuk pengujian validasi asumsi-asumsi klasik yang dimiliki OLS. Ada 3 (tiga) asumsi klasik yang harus diuji berkaitan dengan proses estimasi metode kuadrat terkecil (Ordinary Least Square), untuk mengetahui apakah hasil estimasi 
merupakan estimasi yang bersifat tidak bias linear terbaik (Best Linear Unbiased Estimation, BLUE) atau tidak. Ketiga asumsi klasik tersebut adalah : (1) Tidak terjadi Multikolinieritas antar variabel bebas, (2) Tidak terjadi Heteroskedastisitas, dan (3). Tidak terjadi Korelasi Serial antara residual yang berurutan.

\section{HASIL DAN PEMBAHASAN}

Selama periode penelitian permintaan ekpor kopi Indonesia ke negara Amerika Serikat secara total berfluktuasi, dengan rata-rata sebesar $6,17 \%$ atau sebesar $48.018 \mathrm{~m}$.ton dengan peningkatan tertinggi pada tahun 2009 sebesar 84.010 m.ton dibandingkan tahun sebelumnya. Namun, sejak terjadinya krisis pada tahun 1999 sampai 2003 permintaan ekpor kopi Indonesia mengalami penurunan rata-rata sebesar $-6,97 \%$ atau sebesar $43.020 \mathrm{~m}$. ton dibandingkan dengan tahun-tahun sebelumnya. Sedangkan untuk ekspor kopi Indonesia ke Inggris dengan rata-rata sebesar 42,82 \% atau sebesar 9.039 m.ton dengan peningkatan tertinggi pada tahun 1995 sebesar $23.070 \mathrm{~m}$.ton dibandingkan tahun sebelumnya. Sejak terjadinya krisis pada tahun 1999 sampai 2001 permintaan ekpor kopi Indonesia ke Inggris pun mengalami penurunan rata-rata sebesar $-15,49 \%$ atau sebesar 9. 440 m.ton dibandingkan dengan tahun-tahun sebelumnya.

Seiring dengan penurunan permintaan ekspor kopi Indonesia yang menurun akibat dari penurunan produktivitas hasil tanam, serta adanya kebijakan pemerintah dengan mengenakan pajak sebesar Rp. $30.000 / \mathrm{kg}$ dari volume kopi ekspor dan adanya persaingan dengan kopi yang dihasilkan oleh negara-negara produsen utama kopi dunia (Brasil, Colombia, dan Vietnam) dimana harga kopi terus turun. Selanjutnya pada tahun 20062009 permintaan ekpor kopi Indonesia kembali naik kecuali Inggris pada tahun 2006 mengalami penurunan sebesar -13,93\% dibandingkan tahun sebelumnya. Untuk lebih jelasnya perkembangan permintaan ekspor kopi Indonesia ke negara Amerikat Serikat dan Inggris periode tahun 1981-2005 adalah sebagai berikut :

Dalam ilmu ekonomi umumnya harga ditentukan oleh tingkat permintaan dan penawaran yang terjadi di dalam pasar (mekanisme pasar). 
Hal ini berlaku juga untuk penetapan harga kopi dalam negeri suatu negara. Selama periode penelitian nilai ekpor kopi Indonesia ke negara Amerika Serikat mengalami pertumbuhan yang berfluktuasi, dengan rata-rata sebesar $7,16 \%$ atau sebesar US\$ 82.550 .000 dengan nilai ekspor tertinggi pada tahun 1986 sebesar US\$ 176.100 .000 selama tahun 1985-2009. Pada tahun 2002 sampai 2005 nilai ekpor kopi Indonesia mengalami penurunan dengan rata-rata sebesar $-18.39 \%$ atau sebesar US\$ 67.200 .000 , kemudian pada tahun 2006-2009 kenaikan nilai ekpor kopi Indonesia mengalami kenaikan. Sedangkan untuk nilai ekspor kopi Indonesia ke negara Inggris dengan rata-rata $49.87 \%$ atau sebesar US\$11.940.000 dengan nilai ekspor tertinggi pada tahun 1999 sebesar US\$50.900.000, pada tahun 2002 sampai 2001 nilai ekpor kopi Indonesia mengalami penurunan dengan ratarata sebesar $-24.06 \%$ atau sebesar US\$ 10.280.000. Selanjutnya pada tahun 2006-2009 kenaikan nilai ekpor kopi Indonesia mengalami kenaikan, kecuali pada tahun 2004 nilai ekspor kopi ke Inggris mengalami penurunan sebesar $-10,53 \%$ atau sebesar US $\$ 800.000$.

Selama periode penelitian harga kopi dalam negeri (domestik) mengalami peningkatan dengan rata-rata sebesar $15,77 \%$ atau sebesar $\mathrm{Rp}$. 400.934,48 per-100 kg, dengan harga tertinggi pada tahun 1999 sebesar Rp. 1.327 .183 per-100 kg. Namun, pada periode tahun 2004 - 2007 harga dalam negeri (domestik) mengalami penurunan rata-rata sebesar $-22.94 \%$ atau sebesar Rp. 584.655 per-100 kg. Penurunan harga kopi ini akibat dari terjadinya penurunan harga kopi dunia dan produksi yang melimpah dari negara-negara produsen kopi lainnya. Selanjutnya pada tahun 2008-2009 harga kopi Indonesai kembali naik. Perkembangan harga kopi di pasar internasional berpengaruh langsung pada harga kopi domestik karena sebagian besar produksi kopi Indonesia sangat tergantung pasar dunia. Fluktuasi harga kopi domestik memang tidak persis sama dengan fluktuasi harga kopi dunia karena adanya fluktuasi nilai tukar rupiah terhadap dolar Amerika Serikat. Pada saat harga kopi dunia terpuruk ketitik terendah tahun 2007, petani kopi Indonesia sedikit tertolong oleh melemahnya nilai tukar rupiah terhadap dolar Amerika, sehingga harga kopi di tingkat petani sedikit menguat dibanding harga akhir tahun 2004. Meskipun demikian, harga kopi 
yang diterima petani masih di bawah biaya produksinya. Selama periode penelitian harga kopi luar negeri mengalami peningkatan dengan rata-rata sebesar $5,53 \%$ atau sebesar US\$. 93,88 per-100 kg, dengan harga tertinggi pada tahun 1986 sebesar US\$200.17 per-100 kg. Namun, pada periode tahun 2000 - 2007 harga luar negeri mengalami penurunan rata-rata sebesar $-6,56 \%$ atau sebesar US $\$ 67,47$ per-100 kg, penurunan harga kopi ini akibat dari terjadinya penurunan harga kopi dunia dan produksi yang melimpah dari negara-negara produsen kopi lainnya. Selanjutnya pada tahun 2008-2009 harga kopi luar negeri mengalami peningkatan.

Dalam analisa stabilitas mata uang pada penelitian ini, penulis menggunakan konsep nilai tukar nominal US dolar dan Pound dalam rupiah. Selama periode penelitian nilai tukar mata uang Amerika Serikat mengalami kenaikan, dengan rata-rata sebesar $13,51 \%$ atau sebesar Rp. 4.074,88 perdolar, dengan nilai tukar tertinggi pada tahun 2004 sebesar Rp. 10.400 perdolar. Namun, pada periode tahun 1997 - 2005 nilai tukar mengalami kenaikan rata-rata sebesar 25\% atau sebesar Rp. 8.055,16 perdolar, Sedangkan nilai tukar rupiah terhadap pound dengan rata-rata $13,24 \%$ atau sebesar Rp. 6.723,72 per-pound dengan nilai tukar tertinggi pada tahun 2001 sebesar Rp. 17.888 per-pound.. Kenaikan nilai tukar ini akibat dari terjadinya krisis moneter di hampir semua negara berkembang begitu pula dengan Indonesia.

Selanjutnya pada tahun 2008-2009 nilai tukar rupiah terhadap mata uang dollar relatif lebih stabil, kecuali untuk mata uang pound mengalami peningkatan. Hal ini berkaitan dengan kebijakan pemerintah Indonesia. Indonesia telah beberapa kali melaksanakan kebijakan-kebijakan yang bertujuan untuk memperbaiki nilai tukar rupiah terhadap mata uang kuat lainnya. Berbagai kebijakan tersebut diantaranya adalah sebagai berikut :

1. Devaluasi rupiah sebesar $50 \%$ pada tanggal 15 November 1978

2. Devaluasi sebesar $28 \%$ pada 30 Maret 1983 , dan

3. Devaluasi sebesar $31 \%$ pada September 1980 dan kemudian diikuti dengan depresiasi serial terhadap merosotnya mata uang US dolar 
Kebijakan tersebut dilakukan dengan maksud untuk memperbaiki posisi rupiah dengan mata uang kuat, dalam hal ini adalah US Dolar dan Poudterling. Hal ini disebabkan oleh dipakainya sistem mata uang mengambang terkendali di Indonesia dengan US Dolar sebagai mata uang acuan.

Selama periode penelitian GDP riil negara Amerika Serikat mengalami kenaikan, dengan rata-rata sebesar $3 \%$ atau sebesar US\$ 7.869.850.000.000 dengan GDP riil tertinggi pada tahun 2005 sebesar US\$ 11.134.800.000.000, pada tahun 1988 GDP riil Amerika Serikat mengalami peningkatan tertinggi yaitu $7,38 \%$ atau sebesar US\$ 397.055.898.291 dibandingkan dengan tahun sebelumnya selama periode penelitian. Sedangkan Inggris, dengan rata-rata sebesar $5,17 \%$ atau sebesar US\$ 1.209.408.190.336,35 dengan GDP riil tertinggi pada tahun 2009 sebesar US\$ pada tahun 1988 GDP riil Inggris mengalami peningkatan tertinggi yaitu $5,17 \%$ atau sebesar US\$ 54.373.412.206,80 dibandingkan dengan tahun sebelumnya selama periode penelitian.

Penelitian ini yang dianalisa adalah permintaan ekspor terhadap dua negara mitra dagang yaitu Amerika Serikat dan Inggis, yang diduga dipengaruhi oleh Harga Relatif (rasio harga luar negeri (PLn) terhadap harga dalam negeri (PDn)), GDP riil negara negara tujuan, nilai tukar rupiah terhadap mata uang negara tujuan ekspor dan ekspor kopi Indonesia tahun sebelumnya. Untuk melihat pengaruh masing-masing faktor yang dapat mempengaruhi permintaan ekspor kopi Indonesia meliputi : Harga Relatif (rasio harga luar negeri (PLn) terhadap harga dalam negeri (PDn)), Gross Domestik Produk riil (I), Nilai Tukar (ER), dan Volume Ekspor tahun sebelumnya $\left(\mathrm{Q}_{\mathrm{t}-1}\right)$

Dalam analisis ini akan dijelaskan hubungan dan besarnya pengaruh antara setiap variabel eksogen terhadap setiap variabel endogen. Besarnya pengaruh antara variabel eksogen terhadap variabel endogen dinyatakan oleh koefisien masing-masing variabel eksogen dalam model tersebut. Sedangkan tanda positif atau negatif di depan koefisien tersebut adalah menunjukan arah hubungannya. Apabila koefisien tersebut positif, artinya variabel eksogen itu memiliki hubungan searah dengan variabel 
endogennya. Dengan kata lain, apabila varabel eksogen tersebut meningkat, maka variabel endogen yang bersangkutan juga akan meningkat. Sedangkan bila koefisiennya negatif maka hubungan antara kedua variabel tersebut berlawanan arah. Jadi jika terjadi peningkatan pada varabel eksogen, maka varabel endogennya akan menurun.

Analisis harga dan faktor eksternal yang berpengaruh terhadap permintaan ekspor kopi Indonesia ke Amerika Serikat dan Inggris, yaitu : harga relatif (rasio harga kopi luar negeri terhadap harga kopi dalam negeri), nilai tukar (Exchange rate), Gross Domestic Product riil (GDP riil), dan ekspor kopi tahun sebelumnya. Adapun hasil estimasi dengan menggunakan model regresi linier berganda untuk faktor harga dan faktor eksternal yang mengaruhi permintaan ekpor kopi Indonesia ke Amerika Serikat dan Inggris adalah sebagai berikut.

Nilai harga relatif (rasio harga luar negeri terhadap harga luar negeri) memiliki nilai koefisien sebesar 24.061,758 (Amerika Serikat) dan signifikan, hal ini berarti adanya pengaruh antara rasio harga luar negeri terhadap harga luar negeri dengan permintaan ekspor kopi. Tetapi untuk Inggris memiliki nilai koefisien sebesar 1.377,195 dan tidak signifikan, hal ini berarti tidak adanya pengaruh yang positif antara rasio harga dalam negeri terhadap harga luar negeri dengan permintaan ekspor kopi. Dengan demikian, apabila terjadi kenaikan nilai rasio harga luar negeri terhadap dalam negeri sebesar dolar/rupiah untuk 1000 ton akan menyebabkan peningkatan permintaan ekspor sebesar $24,06 \mathrm{~m}$ ton (Amerika Serikat). Dengan demikian, jika harga relatif (rasio harga luar negeri terhadap harga luar negeri) meningkat maka konsumen Amerika Serikat akan membeli kopi Indonesia lebih banyak karena harga kopi internasional relatif lebih tinggi dibandingkan harga kopi Indonesia dan sebaliknya, karena setiap konsumen dalam melakukan pembelian dengan mempertimbangkan harga yang lebih murah. Sedangkan Inggris, perubahan harga relatif (rasio harga luar negeri terhadap harga luar negeri) tidak memberikan pengaruh yang tidak berarti terhadap permintaan ekspor kopi Indonesia atau dengan kata lain bahwa harga relatif (rasio harga luar negeri terhadap harga luar negeri) menunjukkan tidak ada perbedaan yang nyata (Centeris Paribus), hal ini di 
sebabkan harga bukanlah pertimbangan utama dalam pembelian kopi karena kopi merupakan kebutuhan pokok.

Hasil penelitin ini relevan dan sesuai dengan beberapa teori yaitu: teori (Batiz Fransisco L R dan Luis A. Reivera Batiz, 1994) yang mengemukakan Apabila diasumsikan harga suatu barang di negara $B$ dan $A$ adalah sama, peningkatan harga barang di negara $B$ akan menyebabkan konsumen di negara $B$ mengalihkan pembelian barangnya ke negara $A$ dengan cara mengimpor. Hal ini akan menyebabkan peningkatan ekspor negara A. Dengan demikian maka terdapat hubungan terbalik antara ekspor negara $A$ dengan harga relatif $(P)$ Sedangkan apabila pendapatan negara $B$ meningkat, dan variabel lain diasumsikan konstan (ceteris paribus), maka tambahan peningkatan pendapatannya akan dialihkan untuk pembelian barang-barang dari negara $A$ melalui impor. Hal ini artinya variabel pendapatan berbanding lurus dengan kuantitas ekspor negara A. Demikian juga penelitian Goldstein dan Khan (1978) menunjukan bahwa variabel harga memiliki pengaruh yang signifikan terhadap permintaan ekspor. Secara umum dihasilkan pula bahwa elastisitas harga yang diperoleh lebih besar dari 1, ini menunjukkan peningkatan harga yang sedikit dapat menurunkan permintaan ekspor

Nilai pendapatan riil (GDP riil) memiliki nilai koefisien sebesar 0,476 (Amerika Serikat), 0.055 (Inggris) dan signifikan, hal ini berarti adanya pengaruh yang positif antara GDP riil dengan permintaan ekspor kopi. Hal ini menunjukkan bahwa setiap peningkatan GDP riil Amerika Serikat periode lalu sebesar 1 Milyar US dollar atau Poudsterling akan menyebabkan peningkatan permintaan ekspor Kopi Indonesia sebesar 0, 476 ribu ton (Amerika Serikat) dan 0,055 ribu ton (Inggris). Hal ini menunjukkan bahwa meningkatnya pendapatan akan menyebabkan meningkatnya daya beli konsumen, sehingga dengan meningkatnya pandapatan masyarakat Amerika Serikat ataupun Inggris menyebabkan permintaan akan produk kopi pun meningkat, dan sebaliknya.

Hal ini sesuai dengan Budiono (1982) tentang teori Permintaan bahwa permintaan akan suatu produk $(Q)$ tergantung kepada harga produk $X$, harga barang-barang saingan, harapan akan adanya perubahan harga, 
pendapatan konsumen, selera dan preferensi konsumen, biaya iklan, dan lain-lain. Selanjutnya penelitian kusuma Dewi (2005), ekspor yang terjadi tergantung pada pendapatan negara Pengimpor. Dengan kata lain permintaan ekspor akan bergantung dari pendapatan yang terjadi dimiliki oleh negara tujuan ekspor, selanjutnya identik dengan penelitian Kishor Sherma (2000), bahwa pendapatan penduduk negara pengimpor berpengaruh secara signifikan terhadap ekspor.

Nilai tukar (exchange rate) memiliki nilai koefisien sebesar -0.003 (Amerika Serikat), -0.030 (Inggris) namun tidak signifikan, hal ini menunjukkan adanya pengaruh yang negatif namun tidak signifikan. Pengaruh yang negatif tersebut antara lain disebabkan adanya inflasi di Indonesia, dimana tingkat inflasi lebih tinggi dibandingkan terapresiasinya dolar terhadap rupiah. Pengaruh yang negatif namun tidak signifikan berarti bahwa nilai tukar tidak memberikan pengaruh yang berarti pada permintaan ekspor kopi atau perubahan yang terjadi tidak memberikan pengaruh yang berbeda bagi permintaan ekspor kopi ke Amerika Serikat dan Inggris. Hal ini berarti naiknya nilai tukar (exchange rate) dollar terhadap rupiah maupun poundsterling terhadap rupiah memungkinkan daya beli meningkat. Tetapi pada penelitian ini perubahan nilai tukar tidak menyebabkan peningkatan daya beli yang berarti sehingga berdampak pada perubahan permintaan ekspor kopi Indonesia kurang berarti.

Ekspor tahun sebelumnya $\left(\mathrm{Q}_{\mathrm{t}-1}\right)$ memiliki nilai koefisien sebesar 0,689 (Amerika Serikat), 0.362 (Inggris) dan signifikan, hal ini berarti adanya pengaruh yang positif antara Ekspor tahun sebelumnya $\left(\mathrm{Q}_{\mathrm{t}-1}\right)$ dengan permintaan ekspor kopi. Hal ini menunjukkan bahwa setiap perubahan 1000 ton ekspor tahun sebelumnya $\left(\mathrm{Q}_{\mathrm{t}-1}\right)$ Amerika Serikat maupun Inggris periode lalu akan menyebabkan peningkatan permintaan ekspor Kopi Indonesia sebesar 689 ton (Amerika Serikat) dan 368 ton (Inggris). Hal ini berarti bahwa permintaan ekspor kopi Indonesia untuk negara Amerika dan Inggris tahun Ialu menjadi bahan pertimbangan bagi importer Amerika Serikat atau Inggris dalam upaya meningkatkan volume ekspor kopi Indonesia tahun ini ke negara tersebut. 


\section{SIMPULAN}

Volume permintaan ekspor kopi Indonesia dalam model ini dipengaruhi oleh rasio harga nominal luar negeri terhadap harga nominal dalam negeri, Pendapatan riil negara pengimpor, dan nilai tukar (exchange rate), dengan asumsi bahwa variabel lain dianggap konstan. Untuk ekspor kopi Indonesia ke Amerika Serikat perubahan harga relatif (nilai rasio harga luar negeri terhadap dalam negeri) berpengaruh positif dan signifikan terhadap permintaan ekspor kopi Indonesia. Hal ini berarti apabila terjadi peningkatan nilai rasio harga luar negeri terhadap dalam negeri maka akan menyebabkan peningkatan permintaan, sedangkan untuk ekspor kopi Indonesia ke Inggris pengaruh positif tesebut tidak signifikan.

Perubahan nilai Pendapatan Riil (GDP riil) berpengaruh positif dan signifikan terhadap permintaan ekspor kopi Indonesia ke negara Amerika Serikat dan Inggris, yang berarti bahwa apabila terjadi kenaikan pendapatan riil (GDP riil) menyebabkan peningkatan permintaan ekspor kopi Indoensia. Dengan demikian semakin meningkatnya pendapatan rill Amerika serikat atau Inggris terjadi maka akan menyebabkan peningkatan permintaan ekspor kopi Indonesia. Perubahan nilai tukar (ER) berpengaruh negatif namun tidak signifikan terhadap permintaan ekspor kopi Indonesia. Hal ini berarti bahwa pengaruh apresiasi dolar atau poundsterling terhadap rupiah yang seharusnya meningkatnya ekspor tetapi tidak terjadi , bahkan menurun karena adanya krisis ekonomi yang berdampak tingginya inflasi di Indonesia memberikan pengaruh yang megatif terhadap permintaan ekspor kopi Indonesia.

\section{PUSTAKA ACUAN}

Asosiasi Eksportir Kopi Indonesia. 2002. Kopi Indonesia Jendela Informasi perkopian. Edisi bulan Januari sampai bulan Desember 2002. Badan Pengurus Pusat Assosiasi Eksportir Kopi Indonesia (BPP AEKI). Jakarta.

Batiz Fransisco L R dan Luis A. Reivera Batiz. 1994. International Finance and Open Economy Macroeconomic. Second Edition, New York, Macmillan Publishing Company. 
Budiono, 1982. Ekonomi Mikro: Seri Sinopsis. Pengantar IImu Ekonomi No. 1. BPFE Yogyakarta.

Dumairy. 1996. Perekonomian Indonesia. Yogyakarta : Erlangga.

Goldstein Morris and Khan Mohsin S. 1978. The Supply and demand for Exports : A Simultaneous Approach, The revive of Economics and Statistic is Currently Published by the MIT Press, http://www.jstor.org. Pp 275-286

Greene, William H. 1997. Econometric Analysis. New Jersey : Prentice Hall. Hanke. J. E. and Reitsch. A. G., 1998. Business Forecasting, 6th Edition, Prentice Hall International. Ltd. London.

Herman. 2003. Membangkitkan Kembali Peran Komoditas Kopi bagi Perekonomian Indonesia. Science Philosophy (PPs 762). Graduate Program/S3. Institut Pertanian Bogor.

Kishor Sherma. 2000. Export Growth in India: Has FDI Playeed a Role, Charles stuart university.

Krugrman P. R. and M Obstfeld. 1991. International Economics: Theory and Policy Second Edition. Harper Collins Publisher Inc. New York. USA Krugman, Paul R and Obstfeld, Maurice. 2000. Ekonomi Internasional Teori dan Kebijakan. Jakarta : PT. Indek Kelompok Gramedia-Jakarta.

Kumar, Ramesh \& Ravinder Dhawan. 1991. Exchange rate Volatility \& Pakistan Export to Development World. The review of Economic and Statistics.

Kusumadewi I R. 2007. Faktor-Faktor Yang Mempengaruhi Permintaan Ekspor Tekstil dan Produk Tekstil (TPT) di Indonesia (Tahun 20002005). Tesis Pasca Sarjana Ilmu Ekonomi Universitas Indonesia

Lincolin Arsyad, Drs., M. Sc. 1993. Ekonomi Manajerial - Ekonomi mikro terapan untuk manajemen Bisnis. BPFE Yogyakarta.

Lipsey, R.. G P. N. Courant, D. D. Purvis dan P. O. Steiner. 1995. Pengantar Makroekonomi. Edisi Kesepuluh, Jakarta : Binarupa Aksara

Mankiw, N. Gregory. 2000. Macroeconomics. Fourth Edition. USA : Worth Publishers, Inc.

Samuelson \& Nordhaus. 2003. IImu Mikro Ekonomi. PT. Gramedia Global Edukasi Jakarta. 
Sukirno Sadono. 2002. Pengantar Teori Mikroekonomi. edisi ke 3, Jakarta : PT. Grafindo Persada.

Todaro, M. 1990. Pembangunan ekonomi di dunia ketiga. Jilid II. Second Edition. Cornell University Press, Ithaca and London.

Varian, Hal. 1999. Intermediate Microeconomis: A Modern Approach. W. W. Norton \& Company - New York- London.

Vincent Gaspersz. 2001. Ekonomi Manajerial Pembuatan Keputusan Bisnis. PT. Gramedia Pustaka Utama Edisi Revisi Perluasan. 